\title{
The defence of the honeybee community
}

\author{
By C. R. RibBands \\ Bee Department, Rothamsted Experimental Station, Harpenden, Herts
}

(Communicated by V. B. Wigglesworth, F.R.S.-Received 20 March 1954)

Pairs of colonies of differently coloured bees were placed with their entrances only 2 in. apart, and many bees tried to enter the wrong colony, as if it were their own. Strangers were reeognized by their different scent, and their reception depended upon foraging conditions.

In nectar flows there was no hostility and the bees of both colonies mingled indiscriminately. In fairly good conditions there was no hostility, but partial separation was maintained through the discrimination shown by incoming foragers. In dearth conditions, when bees try to rob other colonies, all strangers were received with hostility; most were thrown out and many were killed.

In dearth conditions marked foragers from one of the two colonies were fed with sugar syrup, but they were nevertheless repelled when they tried to enter the unfed colony; on the other hand, unfed strangers were more readily admitted into the fed colony. Thus hostility to strangers was inversely proportional to the availability of forage; the condition of the community which was to be entered was important, but the behaviour of the intruder was not.

These results are discussed in relation to the defence of the community against both robber bees and strange queens.

\section{INTRODUCTION}

Accumulated food supplies, which can be stolen, provide the honeybee community with a defence problem. Sometimes colonies have to defend their food stores against robber bees from other colonies, and distinction between friends and enemies is of crucial importance to them.

The way in which robbers are recognized has been a matter of dispute. Bethe (1898) thought that different inherited odours were the basis of recognition. Proof of the existence of such odours was not forthcoming, and modern beekeepers have considered that the visibly different behaviour of robber bees accounted for their hostile reception (Cale 1946). Butler \& Free (1952) found that foragers trying to enter the wrong hive (in summer) were seldom attacked, but robbers trying to enter (in autumn) invariably were; they concluded: 'The attacking of robber bees by guards appears to be released entirely by the characteristic horizontal darting of the robber bee...scent is thought to play no part in the recognition of the robber by the guard bee.'

The following results do not support this view : instead, they suggest that differences in body odours are the means by which bees distinguish between friends and enemies; these odours are derived from the different food supplies which are gathered even by adjoining colonies (Kalmus \& Ribbands 1952; Ribbands 1953).

\section{METHoD}

Two colonies of differently coloured bees (one black, one yellowish) were chosen for each experiment. Each colony was put into a hive consisting of a single broodchamber, and the entrances of these hives were closed except for 1 in. apertures, which were on the left side of one hive and the right side of the other. The fronts 
of both hives were then covered with cream distemper. The hives were set down about 3 yards apart and the bees were allowed to fly for several days, until they were fully oriented to these positions.

The two hives were then moved so that they were touching, with their entrances only 2 in. apart. A hive roof was distempered and placed upside down immediately in front of and just below each hive entrance, and a small piece of perforated zine was set up between the two entrances and hive roofs, so that any bees which fell from either entrance would collect in the roof on the same side (figure 1).

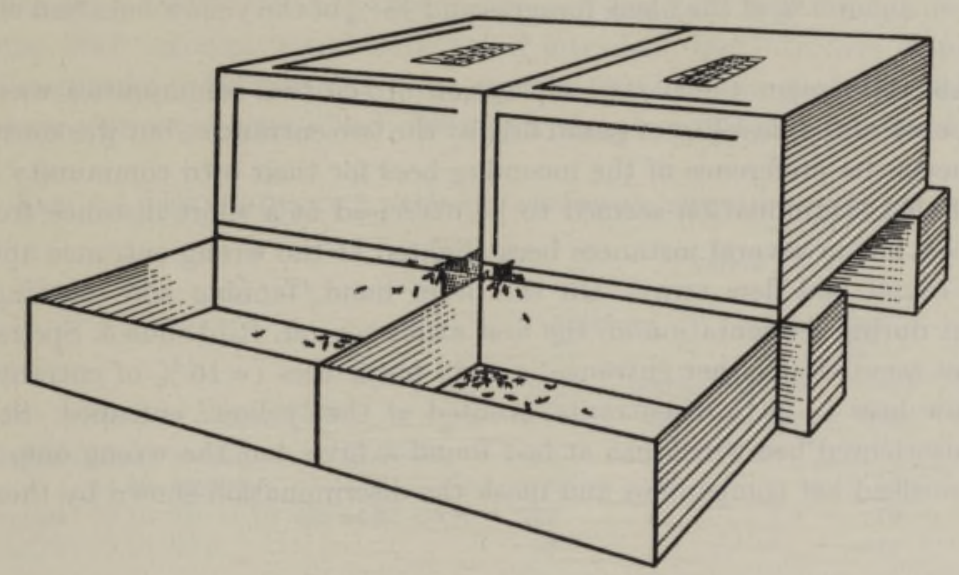

Figure 1.

The flying bees found the new entrances, but as these were so close together they did not satisfactorily orient to the position of one or other of them. Hence many of them tried to enter the wrong hive, as if it were their own. Their successes and failures were recorded. In the experiments the bees were only observed at the times stated, but they were of course flying at other times. Any bee was considered to be rebuffed from an entrance if it landed there and then flew away again, however quickly; these observations are therefore objective.

A trial of the method was carried out on 10 October 1951; there were many combats and casualties, and the colonies remained distinct.

\section{BEHAVIOUR IN GOOD FORAGING CONDITIONS}

Experiment 1 commenced on 28 April 1952, in good flying conditions during the spring build-up. The colonies were placed together at $13.30 \mathrm{~h}$ G.M.T., and observed that afternoon $(13.40$ to $16.00 \mathrm{~h})$ and during the following day $(9.45$ to $11.45 \mathrm{~h}$ and 15.30 to $16.00 \mathrm{~h}$ ). During these periods $46 \%$ of the 3238 bees which returned brought back pollen loads; the presence or absence of a pollen load did not influence their behaviour at the entrance.

There was no hostility at either entrance, but nevertheless incoming foragers exercised considerable discrimination. During the observation periods $75 \%$ of 2284 black bees which returned went into the correct entrance, and $90 \%$ of 954 
yellow ones did so; the discrimination occurred from the very beginning of the experiment, when returning bees had not left from either entrance, and it did not appear to vary significantly during the three periods of observation (it could in fact have increased, any increase being masked by bees which had gone into the wrong hive and become accustomed to it).

On 1 May the proportion of bees which had changed from one hive to another was estimated from counts of outgoing bees; in 15 min 173 yellow and 51 black bees left from the yellow colony, 26 yellow and 649 black bees from the black colony, so about $7 \%$ of the black foragers and $13 \%$ of the yellow ones had changed over.

In this experiment the partial separation of the two communities was not a consequence of the hostility of guard bees at the two entrances, but was most probably due to the preference of the incoming bees for their own community odour. Most of the discrimination seemed to be exercised at a short distance from the entrances, but in several instances bees alighted at the wrong entrance and then turned round and flew away. On the other hand, fanning and scenting were frequent during reorientation on the first afternoon (cf. Ribbands \& Speirs I953) and bees scented at either entrance, e.g. 23 black bees (=16\% of entrants) and 35 yellow bees $(=20 \%$ of entrants) scented at the 'yellow' entrance. Scenting by a misoriented bee which has at last found a hive, but the wrong one, will of course mislead her companions and mask the discrimination shown by them.

\section{BEHAVIOUR IN NECTAR FLOW CONDITIONS}

Experiment 2 commenced on 23 June 1952, when the first lime flowers were coming into bloom. The colonies were placed together at $10.15 \mathrm{~h}$. Foragers at first showed a high degree of discrimination (e.g. between 10.30 and $10.40 \mathrm{~h}$, 47 yellow bees went into their own colony and 13 into the other one) and this was encouraged by the hostility shown to those which erred. This hostility became noticeable at $10.40 \mathrm{~h}$, and soon afterwards guard bees were intercepting arrivals at both entrances. Most of those in error were turned back at the entrance, but a few entered and were afterwards dragged out, either unharmed, injured or dead. The first corpse was a yellow bee which was dragged from the black colony at $10.58 \mathrm{~h}$. Some of the killed bees carried pollen loads.

That afternoon the weather improved, more lime flowers opened, and a heavy lime nectar flow began. This was reflected in the behaviour at the hive entrances, where hostilites ceased. Two days later there were so many foragers that they could not be counted, so outgoing bees were sampled by counting the bees trapped in a conical flask which was placed alternately over either entrance. There were 119 yellow bees $(31 \%)$ in four samples totalling 378 bees taken from the entrance to the hive of the black colony, and 115 black bees $(34 \%)$ in four samples, 343 bees, taken from the entrance of the hive of the yellow colony. Further samples, taken on 30 June, indicated that the bees had mingled indiscriminately; there were 63 yellow bees $(38 \%)$ in samples of 168 bees taken from the black colony and 56 black bees $(57 \%)$ in samples of 99 bees taken from the yellow one. 
More frequent journeys, greater numbers of bees, and speedier travel through the entrances probably contributed to this result by reducing the tendency for discrimination to occur; these factors may have been more important than any reduction in odour differences produced by an abundance of lime nectar in both colonies.

\section{BEHAVIOUR IN DEARTH (ROBBING) CONDITIONS}

Experiment 3 commenced on 20 August 1952. The colonies were placed together at $10.00 \mathrm{~h}$ on a cold and windy day, when very few bees were flying. From the beginning both colonies were hostile to all intruders, but intruders managed to elude the guards; these intruders were mobbed and then dragged out, and many of the bees so treated were killed. Most intruders were tackled by guards at the

\section{Table 1. Experiment 3. Observations at the hive entrances}

periods of observation

\section{August : $10.25-35$ and $10.55-11.05 \mathrm{~h}$ \\ $14.30-15.00 \mathrm{~h}$}

21 August: $10.10-35,11.10-45,14.25-55 \mathrm{~h}$

22 August: $09.10-50 \mathrm{~h}$

20 August: $10.25-35$ and $10.55-11.05 \mathrm{~h}$

$$
14.30-15.00 \mathrm{~h}
$$

21 August : $10.10-35,11.10-45,14.25-55 \mathrm{~h}$

22 August: $09.10-50 \mathrm{~h}$

\begin{tabular}{|c|c|c|c|c|}
\hline \multicolumn{2}{|c|}{ entrants } & \multicolumn{2}{|c|}{ rebuffed } & \multirow{2}{*}{$\begin{array}{l}\text { black } \\
\text { bees } \\
\text { thrown } \\
\text { out }\end{array}$} \\
\hline $\begin{array}{l}\text { yellow } \\
\text { bees }\end{array}$ & $\begin{array}{c}\text { black } \\
\text { bees }\end{array}$ & $\begin{array}{c}\text { yellow } \\
\text { bees }\end{array}$ & $\begin{array}{c}\text { black } \\
\text { bees }\end{array}$ & \\
\hline 13 & 1 & - & - & 1 \\
\hline 9 & 10 & - & 6 & 4 \\
\hline 129 & 24 & 2 & 76 & 12 \\
\hline 43 & 11 & - & 24 & 1 \\
\hline
\end{tabular}

black colony

\begin{tabular}{|c|c|c|c|c|}
\hline \multicolumn{2}{|c|}{ entrants } & \multicolumn{2}{|c|}{ rebuffed } & \multirow{2}{*}{$\begin{array}{c}\text { yellow } \\
\text { bees } \\
\text { throwr } \\
\text { out }\end{array}$} \\
\hline $\begin{array}{l}\text { black } \\
\text { bees }\end{array}$ & $\begin{array}{c}\text { yellow } \\
\text { bees }\end{array}$ & $\begin{array}{c}\text { black } \\
\text { bees }\end{array}$ & $\begin{array}{c}\text { yellow } \\
\text { bees }\end{array}$ & \\
\hline 7 & 5 & - & 1 & 1 \\
\hline 49 & 5 & - & 3 & 15 \\
\hline 228 & 37 & 6 & 61 & 14 \\
\hline 120 & 18 & 8 & 21 & 2 \\
\hline
\end{tabular}

hive entrance, and quickly driven away, but a few stayed at the entrance for some time and were mobbed. The defenders did not necessarily get the better of fights at the entrance, for sometimes an intruder was seen to sting a defender.

Sometimes a bee made repeated efforts to enter the wrong hive, and was turned back on each occasion. In those circumstances its approach became more hesistant and jerky at each new attempt, but when it subsequently went in the same jumpy manner to the entrance of its own hive it was not rebuffed. This observation is subjective, but it is believed to be valid and important and to illustrate the genesis of the characteristic flight of robber bees.

Observations made at the hive entrance are summarized in table 1. Although all intruders met with hostility and $64 \%$ of them were driven away, yet their discrimination between the correct and incorrect entrances (73 and $56 \%$ correct) were lower than that shown in experiment 1 (90 and $75 \%$ correct), where there 
was no hostility. More scent was probably being emitted for orientation during experiment 1 , when more bees were foraging and there were no robbers.

The defence of the community can be measured not only in relation to the $36 \%$ of strangers which succeeded in entering the hives of other colonies, but also in terms of the proportion of these intruders which managed to stay in them. The number of corpses found outside each colony and of live intruders found and killed within the colony on the evening of each day are given in table 2. On the first day the two communities were equally successful, but on the second day the yellow colony was rather less successful - this reduction could be associated with an exercise flight of the black colony, which took place at about $16.50 \mathrm{~h}$. At that time yellow bees clustered in a small knot which almost closed their entrance, and so a high proportion of the very many flying black bees returned to their own colony, but this tactic was not completely successful.

Table 2. Experiment 3. The numbers of SuRviving and of Dead intruders

\begin{tabular}{|c|c|c|c|c|}
\hline & \multicolumn{2}{|c|}{ yellow colony } & \multicolumn{2}{|c|}{ black eolony } \\
\hline & $\begin{array}{l}\text { black } \\
\text { corpses } \\
\text { outside }\end{array}$ & $\begin{array}{c}\text { black } \\
\text { intruders } \\
\text { alive }\end{array}$ & $\begin{array}{l}\text { yellow } \\
\text { corpses } \\
\text { outside }\end{array}$ & $\begin{array}{c}\text { yellow } \\
\text { intruders } \\
\text { alive }\end{array}$ \\
\hline evening, 20 August & 26 & 25 & 58 & 58 \\
\hline evening, 21 August & 81 & 151 & 71 & 78 \\
\hline evening, 22 August & 105 & 381 & 27 & $\infty$ \\
\hline
\end{tabular}

The different results on the third day were attributed to a very big exercise flight by the yellow bees, which was in progress when observations recommenced at $13.30 \mathrm{~h}$ and which lasted for at least 15 min thereafter; the enormous numbers of ingoing intruders overwhelmed the black colony, while many black bees alighting at that time went into the yellow colony's hive with the stream of yellow bees.

During four weeks prior to the experiment large numbers of newly emerged bees in both colonies had been mass-marked with various colours, so that their age would be known. Records of the intrusions of these bees are given in table 3 ; the randomness of the distribution, as between corpses and survivors, indicates that an intruder's chance of survival did not depend upon its age.

Experiment 4 was carried out on 17 September 1952, when the weather was cool and dull and few bees were flying. The hives were placed together at $10.25 \mathrm{~h}$. During the next $75 \mathrm{~min}, 45$ black bees (51\% correct) went into their own hive and 43 tried to enter the other one; only 14 of the latter $(33 \%)$ succeeded. In the same period 52 yellow bees ( $81 \%$ correct) went into their own hive and 12 tried to enter the other one; none of the latter succeeded. At the end of the day 12 yellow corpses lay outside the black colony and 11 black corpses outside the yellow one. Subsequently 3 black bees were found in the yellow colony, no yellow bees in the black one.

In this experiment the fights at the entrance were intensified; whereas in experiment $3,90 \%$ (183 out of 203 ) strangers were quickly turned away, in this experiment $41 \%$ (17 out of 41 ) of the repelled bees fought for a long while. The black 


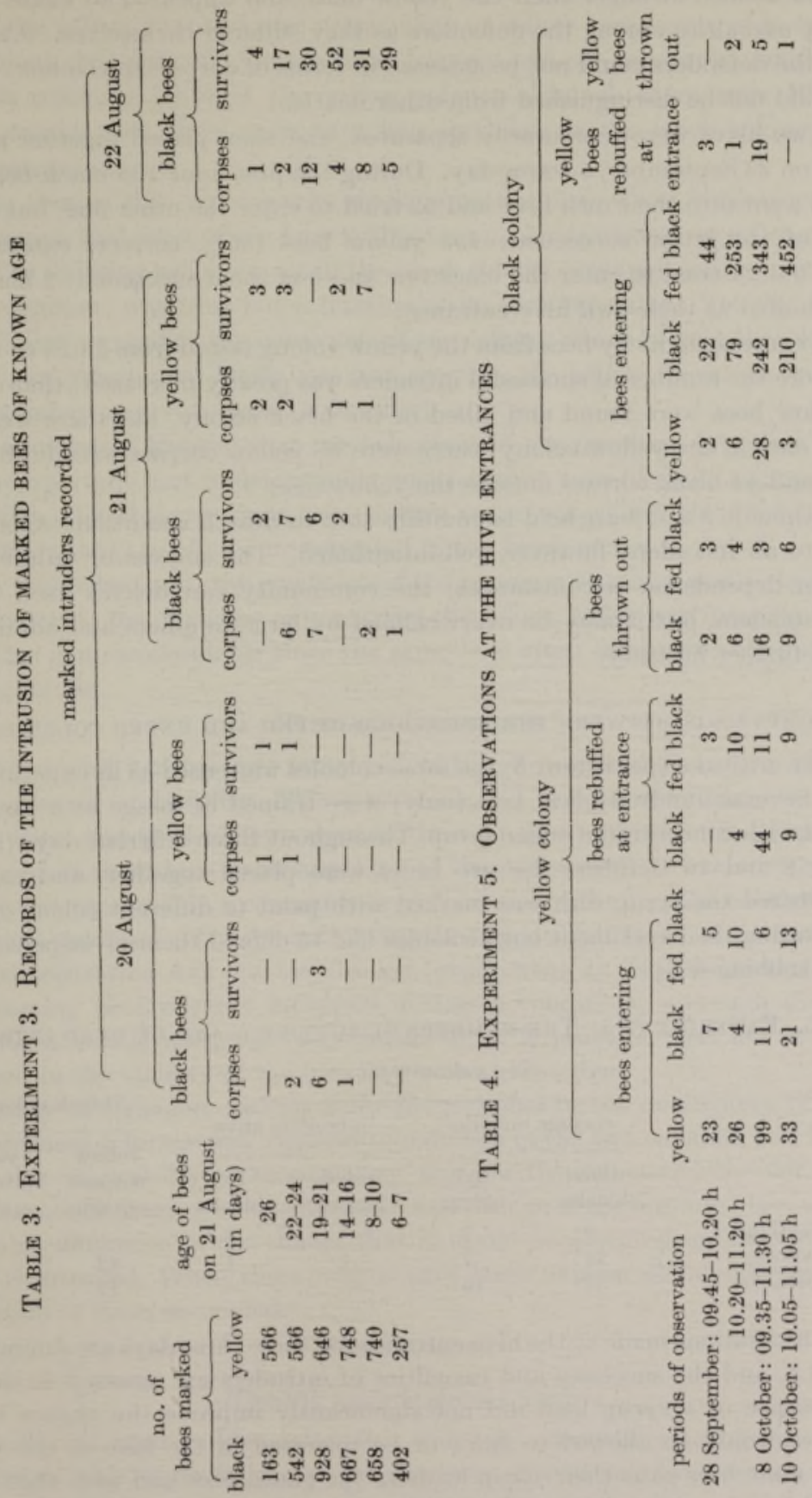


strangers seemed stronger than the yellow ones, and appeared to cause at least as many casualties among the defenders as they suffered themselves. (Casualties among the defenders could not be assessed in terms of corpses in the box, because they could not be distinguished from other deaths.)

The two hives were temporarily separated, and then placed together again at $09.10 \mathrm{~h}$ on 23 September, a warm day. During the first hour 139 black bees $(72 \%$ correct) went into their own hive and 52 tried to enter the other one, but only 13 $(25 \%)$ of the latter succeeded; 153 yellow bees ( $86 \%$ correct) entered their colony, but 24 tried to enter the black one and 6 of them succeeded; 2 black bees were rebuffed at their own hive entrance.

A big exercise flight by bees from the yellow colony lasted from 13.25 to $14.45 \mathrm{~h}$. Once more the number of successful intruders was greatly increased; that evening 315 yellow bees were found and killed in the black colony, but there were only 5 black ones in the yellow colony; there were 58 yellow corpses outside the black colony and 44 black corpses outside the yellow one.

Experiments 3 and 4 are held to indicate that in dearth conditions colonies are hostile to all intruders, however well-intentioned. The success or failure of the intrusion depends on circumstances; the community can defend itself against a few intruders, but it may be overwhelmed by large numbers and admit them without further hostility.

\section{COMPARISON BETWEEN THE BEHAVIOUR OF FED AND UNFED COLONIES}

For the critical experiment 5 , the same colonies were used as in experiments 3 and 4. Several hundred black bees (only) were trained to forage at a Petri dish supplied with concentrated sugar syrup. Throughout three different days (28 September, 8 and 10 October) the two hives were placed together, and each bee which visited the syrup dish was marked with paint (a different colour on each day). During the experiment both colonies had to defend themselves persistently against robbing wasps.

Table 5. Experiment 5. The numbers of SURViving and of Dead intruders

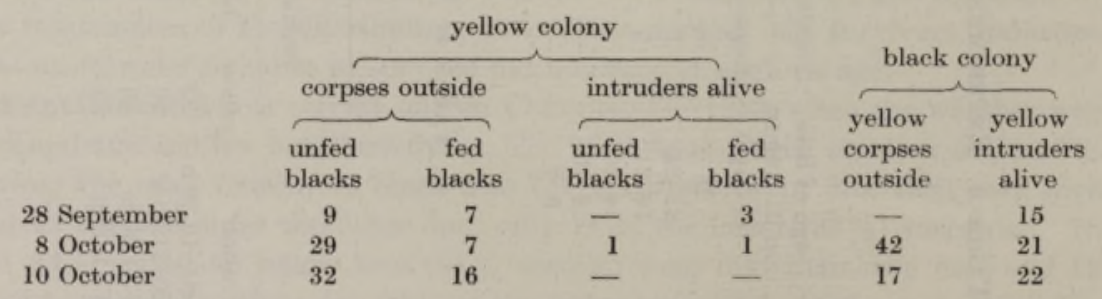

The observations made at the hive entrances on these three days are summarized in table 4, and the successes and casualties of intruders are assessed in table 5 . The presence of a syrup load did not significantly improve the chance that a black bee would be allowed to enter or be tolerated in the hive of the yellow colony; some bees gave their syrup loads to the guard bees and were then stung and killed. 
There was, however, a marked difference between the reception of the black bees by the yellow ones and vice versa; $63 \%$ of yellow bees managed to enter the black colony, but only $45 \%$ of the black bees entered the yellow one; only 5 black intruders remained alive in the yellow colony, although there were 100 black corpses outside, yet there were 58 yellow intruders in the black colony and 59 yellow corpses outside.

At the time of this experiment very little natural forage was available, and one may presume that most of the bees without syrup loads carried no other valuable cargo. The foraging achievement in the black colony, although much greater than in its neighbour, was thus but a fraction of its summer value. Yet this increase was sufficient to modify the behaviour of the colony; one may note that when the ratio of syrup-fed/unfed black bees was greatest, the yellow casualties were least (28 September) and vice versa (8 October).

This experiment showed that the behaviour of the incoming intruders did not play an important part in determining whether they were likely to succeed; black bees which offered syrup loads were thrown out of the yellow colony, but yellow bees with nothing to offer were tolerated in the black one.

On the other hand, the condition of the community which was to be entered was important; the intruders only entered the colony which was foraging successfully. This is understandable since the same bees often carry out both guard and foraging duties.

\section{SuMmaRY OF RESULTS}

In experiment 1 incomplete separation of the two communities was maintained in the absence of hostility. This separation was due to discrimination by incoming bees, and it was shown even in the very first minutes of the experiment when none of these bees knew anything of the position of the entrance of either hive; it was presumably a consequence of their use of community odour for their homeward guidance (ef. Ribbands \& Speirs 1953). During a heavy lime nectar flow the separation was not maintained (experiment 2). This diserimination by the incoming bees was not increased in dearth conditions, although they then met with a hostile reception (experiment 3 ); it is probable that less scent was dispersed in the vicinity of the hive entrance at that time.

Hostility to strangers was inversely proportional to the availability of forage. In experiment 5 forage was supplied to only one of the two colonies, and in those circumstances hostility to strange bees was greatly reduced in the fed colony. The presence or absence of a nectar load, and the age of the incoming bee, made no noticeable difference to the chance that it would be accepted into a colony into which it intruded. When there were a very large number of intruders a higher proportion of them succeeded.

\section{Conclusions}

\section{Hostility towards strange workers}

Hostility to strange bees is innate, and not a learned consequence of any detrimental activity on the part of the strangers. Beekeepers have to take account of this hostility, and the precautions which they take when uniting colonies 
provide a good example (e.g. Cale 1946). Under experimental conditions innate hostility, readily modifiable by cireumstances, is shown in the experiment of Kalmus (I94I), who trained bees from two differently coloured colonies to a dish of sand covered with sugar syrup; as soon as the syrup supply became sparse squabbling occurred, but only between the bees of different colonies. Lecomte (195I) found that groups of 20 to 30 queenless bees, alone in a cage, were often hostile to strange workers introduced among them.

In my experiment 3 there was innate hostility in the absence of any robbing, and that hostility was readily modified when a heavy nectar flow commenced. Variations in the extent of the hostility are readily explicable. Defence is primarily a duty of the older bees, which are also foragers or potential foragers, and they cannot earry out both duties at the same time. When there is no forage these bees may remain at home, as irritable guard bees, or go to plunder other colonies, as robber bees; they may undertake both activities in turn (Butler \& Free 1952). Conversely, during a good nectar flow no bees act as guards, and there is no need for them because robbing is a less profitable occupation than nectar-gathering.

\section{Recognition of strange workers and of robber bees}

Lecomte (195I) introduced strange workers among small groups of bees in cages, and noted that the strangers were less likely to be attacked if they kept still. Then he introduced various decoys. There were many attacks on decoys which were bobbed up and down, but there was only one attack on an immobile decoy (a dead bee), so Lecomte concluded that movement was the most attack-provoking stimulus. Butler \& Free (1952) used dead bees as decoys, and jerked them up and down in front of colonies; there were as many attacks upon freshly killed hivemates as upon dead strangers, and these results were construed as evidence that robber bees are recognized by their distinetive flight, and not by a distinetive odour.

These two interpretations neither ask nor answer two significant questions. Why does the normal movement of a strange bee provoke attack? Why do robber bees adopt a different mode of flight, if it betrays them?

Moreover, the interpretation of the results is less straightforward than may appear at first. Bees in a colony are incited to attack by any quick and strange movement in their vicinity, as beekeepers know, and the jerked corpses may have provided such a stimulus; moreover, a vertically jerked dead bee looks different from any living flyer; the difference between the flight of a robber and of a returning forager is much more subtle, and less likely to be recognized, and so the results obtained with jerked corpses do not necessarily measure the relative importance of movement and scent in recognition.

By contrast, the results now recorded imply that strange bees are recognized by their foreign odour. The intruders alighted at the hive entrance as if it were their own; the discrimination which was shown between the entrances (experiments 1 and 2) suggests that they recognized that they were not in their own hive entrance, but some intruders fanned and scented (experiment 1), others offered food (experiment 5) and none were aggressive. It is probable that some of them hesitated, but Lecomte's results suggest that such behaviour would rather tend 
to inhibit attack than to provoke it.* Thus no circumstance in the behaviour of these intruders would of itself have provoked attacks upon them.

Kalmus \& Ribbands (1952) demonstrated the presence and origin of odours by which the bees of any colony recognize their companions in the field and distinguish them from the honeybees of other colonies. The scent perception of honeybees is acute (Ribbands I954), but their vision has considerable limitations (summarized Ribbands 1953). These facts indicate that smell, not sight, is the means of recognition of intruders at the hive entrance.

This hypothesis will explain why the strange bees introduced by Lecomte were often attacked. It will also explain satisfactorily the origin of the characteristic flighting of robber bees - if they are recognized by smell, and repeatedly attacked, anticipation of more of this punishment might produce the querulous flight by which man can recognize them. This mode of flight would then be the consequence of recognition, not its cause, but this would not preclude the possibility that it might then contribute in some degree towards their subsequent recognition and discomfiture. One could not otherwise understand why robber bees adopt a distinctive pattern of behaviour which is supposed to be to their own disadvantage.

Repeatedly rebuffed intruders acquired a flight which approached that of robber bees, but they were nevertheless admitted without hostility when they went to the entrance of their own hive in this manner; these observations emphasize the predominant role of scent in recognition.

In one of the experiments of Kalmus \& Ribbands (1952) foragers were attracted from a distance to the dish on which their companions had recently ceased to forage. The distinctive odour which exerted this attraction is mainly given out from a scent organ at the tip of the abdomen (Sladen 1902). Recognition was therefore a response to a chemical stimulus, appreciated in vapour form, and appropriately termed an odour. The odour of intruding workers and robber bees (which would not aid their own discomfiture by exposing their scent organ), presumably comes from isolated gland cells which are scattered over the whole integument of the honeybee and which are of the same structure as those which are concentrated in its scent organ (Jacobs 1924).

Insects may perceive odours through direct contact between their antennae and the source (Forel 1908), and in the present experiments it is likely that intruding bees were usually recognized after such contact.

\section{Recognition of and hostility towards strange queens}

The results, which are concerned with the defence of the community against robber bees, are relevant to its attitude towards a strange queen.

Parasitic solitary bees, which elosely resemble their host and have evolved from the same ancestors, occur in all other subfamilies of social bees, but not among

* However, if the intruders were recognized by scent alone hesitation might sometimes increase the chance of interception. Butler \& Free (1952) interchanged a pair of hives, in one of which there were a large number of 18-day-old bees (marked blue) and 28-day-old bees (marked white); 22 out of 29 of the younger bees, but only 16 out of 75 of the older ones, were intercepted by guards; it was suggested that the older bees were dominant, the others submissive, but it seems to me likely that the younger bees were less well oriented to the entrance and therefore more likely to hesitate. 
honeybees (Wheeler 1928). The recognition and rejection of strange queens, as a defence against such usurpers, would explain why it is sometimes difficult to introduce a new queen to a queenless colony or to exchange queens between colonies (Ribbands 1953).

The queen is recognized as a queen in addition to any possible recognition as a member of the community. Moreover, most difficulty occurs in the introduction of virgin or non-laying queens into colonies deprived of laying queens (e.g. Doolittle 1915 ; Snelgrove 1940 ), which suggests that the bees can recognize the fruits of differences in the queen's egg-laying activity.

The queenly component of the recognition is of much greater importance than any communal component, and the latter has not yet been separately demonstrated. I think that it exists and is the cause of queen losses which occur occasionally after immediate exchanges of similar queens in similar colonies. Variations in queen losses are parallel to variations in the acceptance of strange workers. In both queen and worker introduction antagonism is (i) minimal during a nectar flow, (ii) maximal during robbing, (iii) increased by disturbance of the colony, (iv) reduced if the bees are confused (as when very many strange workers attempt to enter). Moreover, although bees seem to prefer their own queen to another they may welcome a stranger if they are queenless, as lost strangers may fan at the entrance to the wrong hive.

Queens do not possess a specialized scent organ (Jacobs 1924). Von ButtelReepen (1900) noted that a queen cage from which a queen had just been removed caused queenless bees to fan; yet a caged queen, placed 14 in. in front of the entrance to a queenless colony, was not noticed by the many flying bees. These results, and those of Hess (1942) and Müssbichler (1952) in relation to laying workers, indicate that queen recognition is not exactly parallel to worker recognition; taste (Butler, unpublished) or contact odours may play a proportionally greater part in queen recognition, the recognized substances being either less volatile or present in much smaller quantity than those involved in worker recognition.

\section{REFERENCES}

Bethe, A. 1898 Pflüg. Arch. ges. Physiol. 70, 15-100.

Butler, C. G. \& Free, J. B. 1952 Behaviour, 4, 263-92.

Buttel-Reepen, H. von $1900 \mathrm{Biol}$. Z Zbl. 20, 1-82.

Cale, G. H. I946 In The hive and the honeybee, ch. IX and xiv. Hamilton, Illinois: Dadant. Doolittle, G. M. 1915 Scientific queen-rearing. Hamilton, Illinois: Dadant.

Forel, A. 1908 The senses of insects. London: Methuen.

Hess, Gertrud 1942 Beih. schweiz. Bienenstg., 1, 33-109.

Jacobs, W. 1924 Z. Morph. Ökol. Tiere, 3, 1-80.

Kalmus, H. I94I Nature, Lond., 148, 228.

Kalmus, H. \& Ribbands, C. R. 1952 Proc. Roy. Soc. B, 140, 50-9.

Lecomte, M. J. I95I Behaviour, 4, 60-6.

Müssbichler, A. 1952 Z. vergl. Physiol. 34, 207-21.

Ribbands, C. R. 1953 The behaviour and social life of honeybees. London: Bee Research Association.

Ribbands, C. R. 1954 (Submitted for Proc. Roy. Soc. B).

Ribbands, C. R. \& Speirs, Nancy 1953 Brit. J. Anim. Behav. 1, 59-66.

Sladen, F. W. L. 1902 Ent. Mon. Mag. 38, 208-11.

Snelgrove, L. E. 1940 The introduction of queen bees. Bleadon, Somerset: Snelgrove.

Wheeler, W. M. 1928 The social insects. London: Kegan Paul. 